\title{
Development of Comic Based on Local Wisdom as Learning Media for Primary School
}

\author{
Hidar Amaruddin', Haryadi, Eka Sari Setianingsih ${ }^{2}$ \\ ${ }^{1,2}$ Graduate School, Universitas Negeri Semarang, \\ Corresponding email: hidar@gmail.com
}

\begin{abstract}
The background of this study is the need for learning media in Indonesian language subject text conversation on the kids' grade primary school. The problem is how the development of media KORIKA as a media learning of the Indonesian language students grade primary school? The aim of this study is to develop KORIKA media and know the process of development in the media learning the Indonesian language text conversation on the kids' grade primary school. It is a research and development using Borg and Gall's theory. The development of media KORIKA produces media learning in Indonesian language subject conversation text grade school curriculum first semester in the education of 2006. Based on the results of this research suggestion that can be delivered is so the media KORIKA can be used as one alternative media.
\end{abstract}

Keywords: Comic, local culture, values character, text conversation, Indonesian language

\section{Introductions}

Education is valued as an absolute right for all children across Indonesia, because they will lead and continue Indonesian struggle soon. According to Trianto (2014:3), the quality of education was aimed at increasing the quality of Indonesian throughout performance in order to have competitiveness due to global defiance. Education does not loses its touch if the process of learning in the classroom, especially in the implementation of the teaching material in a classroom, a teacher needs to apply learning strategies which s/he suits accordance to the situation and the existing condition. One of high skill often considered trifling in this era of globalization; it is read and write. When in reality, kids' interest of reading and writing is very far from what we expected, even though they live in the country. Interest in reading makes your writing rich and expand. Set out from andragogy understanding that when writing is the output result of reading. As by reading is a main reference in skills.

In the class $\mathrm{V}$ of primary school, there are topics on the text of a conversation or dialogue. The development of teaching and learning variation done by teachers also be one example in the media use in learning which is unique and flexible.

By creating something new in the development of teaching materials as well as a media and not only arising students' interest of reading but also can increase the rate of students' creativity in writing, recite intonation in a conversation that just as practice and inserting character values in the story wisdom local culture to students. For that it is needed to make a new product media of the board comic in which there was story local knowledge to teach learning the Indonesian language subject text conversation at grade 5 primary school students.

Therefore, this study aims to answer the research problem; "How development of KORIKA media (the comic story local knowledge) that is said to be used as a learning media in the Indonesian language material conversation text for kids grade primary school?"

\section{Methods}

There was almost similar thing was conducted and published in some journals. The researchers made those journals as a reference under study which are relevant.

According to journal entitled "Pengembangan Media Komik Bergambar Materi Sistem Saraf Untuk Pembelajaran Yang Menggunakan Strategi PQ4R" by Ary Nur Wahyuningsih, a teacher of the gentiles who opens its market to foreign Bojong for the first junior high school teachers given by the Pekalongan district. They stated if the implantation of the star in comic book in learning activities would be able to deliver a stimulus types of motivations and of such interest to the successful students at the staple of the most treasured subjects that are considered the economic growth after experiences very difficult intense play to be figured out, stimulate the activity of discussion, build an 
understanding and extend a retentive memory students.

In the journal called "Penggunaan Media Komik Untuk Meningkatkan Ketrampilan Membaca Cerita di Kelas V Sekolah Dasar" by Jufri Ahmat and Sukartiningsih at the university of Surabaya, they stated that cartoon will be very interesting because there are reading and also pictures contained in the media comic, they make it easier for students to understand the meaning of implied and content that contained in the story. Next is a study entitled "Penerapan Metode Bercerita Berbasis Kearifan Lokal Untuk Meningkatkan Moral Anak Kelompok B PAUD Widya Laksmi" made by Ni Kadek Eka Jayanti, Ketut Pudjawan, and Luh Ayu Turtayani from the university of Ganesha. They stated that one of alternative choices to be done to improve the learning process and even improve the values of the character of a child is by an activity or learning related with the story/ a fairy tale with local cultural wisdom based.

The research design used by the researchers is research and development (RnD) to develop KORIKA media.

\section{Results and Discussion}

The selection of media that is based on the existing problems in the field in primary school 01 Sadang Bulungcangkring and other primary schools, where teachers still uses the method of learning using conventional talk. In addition, there is another problem from social aspect that is students' lack of reading interest. The impact caused by the lack of understanding on students' the dialogue/ conversation, understanding. They also have not been able to practice for the correct expression and intonation. Then in terms of making conversation is very simple, because of their lack of creativity.

To make this media that is set off of the invention of the research conducted by her earlier comic researcher. "Comic can be defined as a form of cartoons that expresses the character and plays a story in the order closely connected with images and designed to given pleasure to readers. (Sudjana \& Rivai, 2013: 64). Then the researcher does not only make comic but also want to make what is also considered interesting and unique media. There are syntactic, rewards and punishment. Not only have that researchers wanted to add content local knowledge on the story that is contained in KORIKA. "Having the local wisdom values has been positive in transfer to kids in order to form the personality which characterless." (Mulyani, 2015: 57)

This media is conversation text that is very flexible. It is applied to the Indonesian language subject grade 5 primary school. The standard competency created is based on decree of 3; understand a text by reading the text conversation, recite rapidly 75 minute. Basic competence 2.3; read the text of the conversation with proper intonation, and 4.3; write simple dialogue between two or three figures by taking into account the contents of its. In general was used in the study method of development (research and development. According to (Sugiyono, 2015: 407-427), there are ten steps in research and development in the regulation of education study. Reality the primary school teachers, of the faculty of education, the university of PGRI Semarang simplified into three stages; 1) the study introduction, 2) that stage of development, 3) testing stage. Based on the policies of the study and the formulation of a problem, so it is done only until trial phase products.

The following efforts being made by the researchers the potential for and problems of the $1,2)$ data collection/ information, 3) design a product, 4) validation products, 5) the revision of design a product, 6) pilot products. Based on stage that obtained as the research results used to evaluate media material KORIKA text conversation, on introduction stage two primary school were interviewed before doing research. A number of problems especially literation in Indonesian language subject were found. Most of them have the same problem that teachers still use conventional methods, though not forever that method is less attractive, but when s/he continuous doing that then the children are bored. Each teacher at grade 5 did not have media yet when they teach conversation text in Indonesian language subject.

Set out from the previous studies and the development of the next stage of the study. Of course researchers then developing of KORIKA media indirectly in a fully formed state. These forms of media experienced various revision in the perspectives of the media and the material, so as to produce media that it is said worthy to try out in the field is urgently needed.

When it came to the trial phase product to apply KORIKA media to their students of grade 5 primary school, researchers did observation at the first day to the latter when there were in the class. On the first day they 
obtained several students learned the most about material conversation after evaluation carried out by class teacher. Interviews were conducted and there was, indeed, a need of media to teach conversation material. The second day, the students in the class looked a little bit enthusiastic when learning began, they must submit conversation briefly and vividly, but the concentration of students lasted only a few minutes. The rest of the students more comfortable in playing and joking with his friends. The third day, the students learnt using KORIKA media. Apparently, they were enthusiasm and more focused due to the concrete media. Learning was conducted in accordance with syntactic a media game. In three aspects cognitive, affective and psychomotor students can run well. The rewards and punishment included in steps of KORIKA media, improve the study active, students compete in order to read the text conversation and proper intonation. The evaluation proofed that there is difference in students' scores before and after using KORIKA media.

Through the survey of students' interest received the percentage excellent $90 \%$ of students were interested in using this media. Although there are students who said some questions about the survey interest, but the results percentage showed that KORIKA media is effective and interesting.

The data and results obtained from the evaluation students that the average value of pre-test class was 45.31 . Then, the post-test class obtained by learning the application of KORIKA media the average value was 75.06. It shows the difference value of the students' evaluation in learning the Indonesian language by the application of KORIKA media to their students of grade 5 in 03 Sadang primary school. Thus, this research in learning the Indonesian language text conversation material uses the KORIKA media shows satisfactory results and better than the material learning the Indonesian language text conversation without the use of any medium.

Based on the results of hypothesis test calculation by using $\mathrm{t}$ test obtained $\mathrm{t}=19.879$ and $\mathrm{n}=16$, $\mathrm{df}=16-1=15$, then the price $\mathrm{t}$ table for error level $5 \%=2.13$. For $\mathrm{H} 1$ is acceptable if $\mathrm{t}$ count $\geq \mathrm{t}$ table, so because $\mathrm{t}$ count $=19,879>\mathrm{t}$ table $=2.13$ then $\mathrm{H} 1$ accepted and Ho rejected. It can be concluded that KORIKA media imposition effective against the subject matter text translation of Indonesian language $\mathrm{V}$ in 03 Sadang primary school.

According to Siregar (2014: 144), evaluation of study result is all kinds of procedure that is used to obtain information on to show off work performance students or students to meet targets that have been set by learning. KORIKA media can be used not only students to improve learning outcomes in the knowledge or understanding, but also to be active, motivated and implicitly delivered character values that which is sublime. This is evidenced by the value data of effectiveness obtained in this study.

\section{Conclusion}

Development of media KORIKA produces material media learning of the Indonesian language text conversation grade 5 primary school in the first semester of 2006 level of education curriculum. Validation of testing an expert media with the percentage of $81.18 \%$ with two categories of very good, the people of the matter with the percentage of learning 90.67 $\%$ with two categories of very good. There were also suggestions (validator input) to engage the attention of the media and to do a little improvement or revisions so the media can be more perfect.

\section{References}

Ahmat, Jufri. (2013). "Penggunaan Media Komik Untuk Meningkatkan Ketrampilan Membaca Cerita di Kelas V Sekolah Dasar". Universitas Negeri Surabaya, http://ejournal.unesa.ac.id/, 27 September 2016.

Alwi, Hasan et al. (2010). Tata Bahasa Baku Bahasa Indonesia. Jakarta: Pusat Bahasa dan Balai Pustaka.

Arsyad, Azhar. (2014). Media Pembelajaran. Jakarta: Raja Grafindo Persada.

Asyhar, Rayandra. (2012). Kreatif Mengembangkan Media Pembelajaran. Jakarta: Referensi Jakarta.

Gumelar, M S. (2011). Comic Making Cara Membuat Komik. Jakarta: PT Indeks.

Hartono. (2012). Statistik Untuk Penelitian. Yogyakarta: Pustaka Pelajar

Jayanti dkk. (2016). "Penerapan Metode Bercerita Berbasis Kearifan Lokal Untuk Meningkatkan Moral Anak Kelompok B PAUD Widya Laksmi”. Universitas Pendidikan 
http://ejournal.undiksha.ac.id/, September 2016

Mulyani, Mimi. (2015). PROCEDING INTERNASIONAL SEMINAR 2015"Pengitergrasian Kearifan Budaya Lokal Dalam Pembelajaran Literasi di SMP”. Semarang: Sultan Agung Islamic University.

Sudjana, N dan Rivai, A. (2013). Media Pengajaran. Bandung: Sinar Baru Algesindo.

Nurhasanah, Siti. (2012). Pengembangan Bahan Ajar Membaca dan Menulis Teks Percakapan Untuk Siswa Kelas V SD.

Yulisetiani, Septi. (2015). PROCEDING INTERNASIONAL SEMINAR 2015. Pendidikan Berkearifan Lokal dalam Cerpen Ikan Kaleng Karya Eko Triono". Semarang: Sultan Agung Islamic University.
Siregar, Eveline dan Nara, Hartini. (2014). Teori Belajar dan Pembelajaran. Bogor: Ghalia Indonesia

Wahyuningsih, Ary Nur. (2011). "Pengembangan Media Komik Bergambar Materi Sistem Saraf Untuk Pembelajaran Yang Menggunakan Strategi PQ4R".SMP Negeri Bojong 1 Kabupaten Pekalongan,http://journal.unnes.ac.id/, 27 September 2016

Slameto. (2010). Belajar dan Faktor-Faktor Yang Mempengaruhinya. Jakarta: Rineka Cipta

Sugiyono. (2015). Metode Penelitian Pendidikan (Pendekatan Kuantitatif, Kualitatif dan R\&D).Bandung: Alfabeta.

Trianto. (2014). Model Pembelajaran Terpadu. Jakarta: Bumi Aksara.

Yudiono, K.S. (2009). Cerita Rakyat Kendal. Jakarta: Grasindo. 